\title{
Falsificações Arqueológicas na Turquia
}

\author{
Ergün Lafli * \\ Maurizio Buora** \\ Claudia Gradim***
}

LAFLI, E.; BUORA, M. GRADIM, C. Falsificações Arqueológicas na Turquia. R. Museu Arq. Etn. 36: 23-45, 2021.

Resumo: Este artigo discute a autenticidade arqueológica na Turquia dos pontos de vista científico-acadêmico e popular. Na Turquia, "falsificações arqueológicas" que um dia receberam pouca atenção tem criado debates públicos nos últimos cinco anos. Apesar de já conhecido, o problema não era abordado de forma constante em pesquisas científicas. É provável que ainda tenhamos um longo caminho até que os arqueólogos turcos sejam capazes de lidar com este assunto em termos científicos e aceitá-lo como um importante campo de estudos. Embora a Turquia seja um país-chave tanto para a descoberta de originais quanto para a produção de falsificações, sabemos pouco sobre quais materiais devem ser categorizados como réplicas ou falsificações, quais objetos foram classificados, quais materiais foram falsificados, por que e por quem. Estima-se que o número de falsificações expostas em museus locais seja muito alto, incluindo inúmeras lamparinas, moedas, objetos metálicos (especialmente de prata) e pedras preciosas. Nos mercados internacionais conhecemos vários tipos de objetos que foram falsificados na Turquia, uma vez que é particularmente difícil distinguir entre moedas autênticas ou falsificações modernas, por exemplo. Diversos escândalos de falsificação em museus turcos surgiram nos últimos dez anos. Há duas explicações para os enganos: os administradores do museu não sabem nada sobre as falsificações, ou há outras razões pelas quais tais itens são apresentados como reais em exposições. Este artigo acompanha um catálogo amostral para a reanálise dos artefatos utilizando múltiplos critérios para a determinação de sua não autenticidade.

Palavras-chave: Falsificações arqueológicas; Réplicas; Imitações; Autênticos; Museus turcos.

\footnotetext{
* Professor de Arqueologia Clássica na Dokuz Eylül University. Para consultar outras publicações do autor, ver: $\langle$ https://deu. academia.edu/ErgunLAFLI>. <ergun.lafli@deu.edu.tr>

** Società Friulana di Archeologiam Udine. Ex-director of Civici Musei Udine. To consult other publications by the author: $\langle$ https://independent.academia.edu/ mauriziobuora >.<mbuora@libero.it>

*** Tradução. Mestre em Arqueologia pelo Programa de Pós-Graduação em Arqueologia da Universidade de São Paulo (PPARQ-USP). <claudia.gradim1963@gmail.com>
}

\section{Introdução}

A partir dos anos 1980, muitas coleções locais têm aparecido na Turquia (Fig. 1), principalmente por meio de aquisições. Ao mesmo tempo, o pessoal técnico e científico dos museus locais turcos foi reduzido à metade (de 1500 para 750 arqueólogos). Esse fato, combinado à inclinação humana natural 
para a fraude e os ganhos ilícitos, encorajou a presença de cópias e falsificações em museus. Comerciantes de antiguidades em museus turcos de quem os produtos são comprados geralmente alegam que os acharam em sítios antigos. Este estudo de caso também levanta questões relativas ao uso de objetos sem proveniência comprovada, como dados arqueológicos, na reconstituição arqueológica da Ásia Menor.

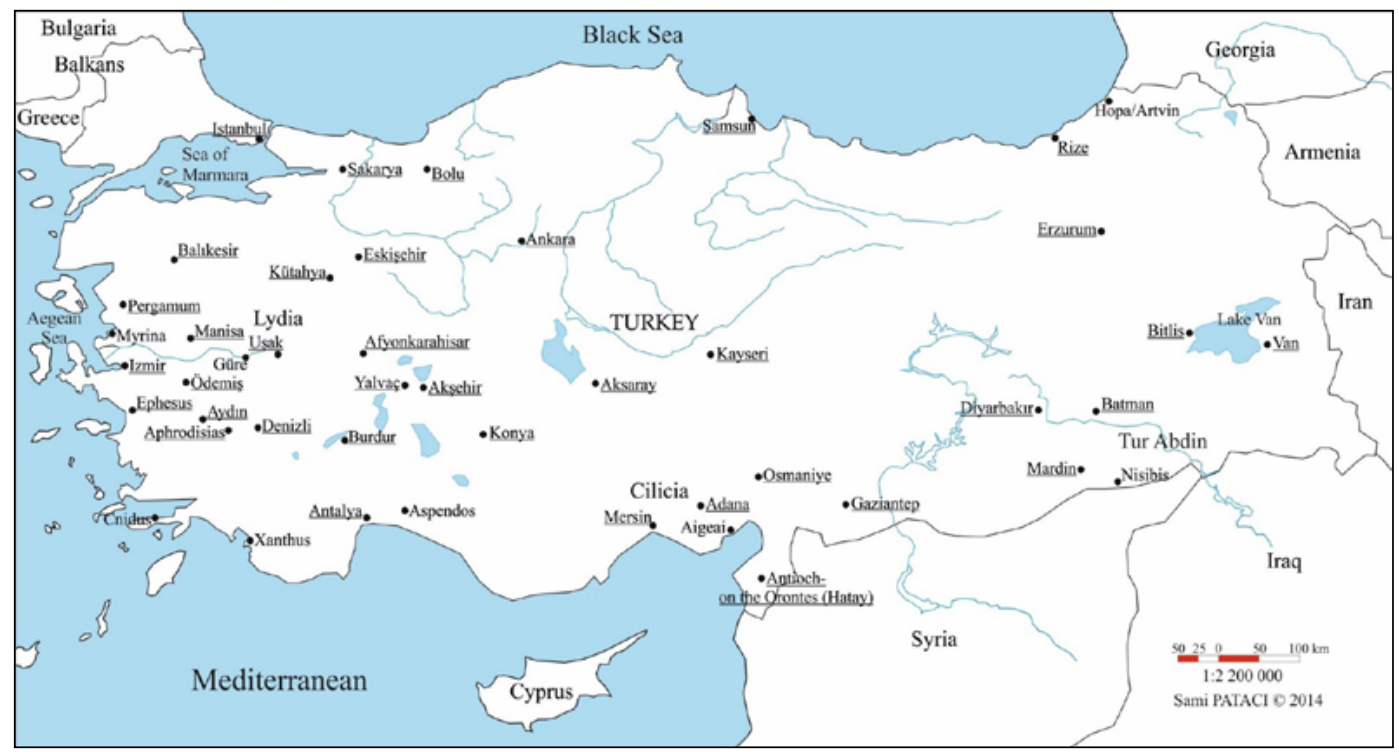

Fig. 1. Lugares da Turquia mencionados.

Fonte: Pataci (2014).

O tráfico ilegal de antiguidades falsificadas é considerado pela polícia internacional como o terceiro maior mercado do mundo, atrás apenas do tráfico humano e do de drogas (Bowman Proulx 2011: 192). Nos últimos cinco anos na Turquia, o debate até então discreto acerca da "falsificação arqueológica" tornou-se público. Esse problema já era conhecido, mas incomum em pesquisas acadêmicas. Ainda teremos, provavelmente, um longo caminho pela frente até que arqueólogos turcos passem a tratar desse assunto em termos científicos, aceitando-o como uma importante área de estudo. Apesar de a Turquia ser um país-chave tanto para artefatos originais quanto cópias, sabemos muito pouco sobre quais objetos foram falsificados, por quem e por quê. $\mathrm{O}$ mercado de antiguidades e o desenvolvimento dos estudos sobre o antiquarianismo na América do Norte e na Europa Ocidental alimentaram o crescimento de indústrias domésticas envolvidas no saque de sítios arqueológicos e de falsificações na Turquia.

Ali, o número de falsificações em exposição nos museus locais, incluindo lamparinas, moedas, objetos de metal (especialmente prata e ouro) e pedras preciosas, é maior do que o estimado. Em mercados internacionais, temos conhecimento de diversos itens arqueológicos que foram forjados na Turquia.

É particularmente difícil distinguir moedas falsas de verdadeiras. Como fazê-lo? Naturalmente, o estudo do material deveria ser o primeiro passo. Arqueólogos sabem de quais pedreiras provinham os mármores que os artistas da Antiguidade costumavam usar, dependendo da área e da época, e as antigas ligas metálicas também são conhecidas. As fraudes têm duas explicações: ou as autoridades museológicas nada sabiam sobre elas, ou há outras razões para apresentá-las como autênticas. 
Nas coleções turcas, muitos artefatos parecem enganosamente realistas. Contudo, graças a métodos científicos, tais como datação por termoluminescência, carbono radioativo, ativação de nêutrons, análise de fluorescência de raio $X$, pesquisas magnetométricas etc., é possivel determinar a idade, a composição e a autenticidade de um objeto arqueológico, e também revelar a estrutura e a constituição dos metais. Recentemente, falsificações arqueológicas foram descobertas sobretudo por análises químicas (Aydın 2013a: 170-171; Aydın 2013b; Craddock 2009: 7-8; Mezzasalma et al. 2009): todo material cerâmico conserva a radioatividade de urânio, tório e potássio naturais. Essa baixa radioatividade pode ser visualizada na forma de luzes quando o material é aquecido a aproximadamente 500 graus Celsius (Spier 1990: 624-625).

Por quem e por que razão artefatos arqueológicos são falsificados? A maior parte das falsificações do mundo tem origem em regiões que ainda não possuem nem meios sofisticados de análise, nem conhecimento suficiente dos materiais e métodos de manufatura - por exemplo, África Ocidental e China, mas também Itália meridional, Grécia e Turquia (Holtorf 2013: 429). Na Turquia, o artesanato tradicional ainda impera ${ }^{2}$. Normalmente, envolve a produção em massa de itens de baixo valor, pois forjar peças de alto valor científico não compensa. Atualmente, a atividade dos falsários turcos apresenta algumas semelhanças com as das organizações mafiosas. Nesses grupos, efetivamente, as contrafações são mais profissionais, mas para os arqueólogos ainda é possível expor suas dúvidas, mesmo desconhecendo sua origem.

Nas seções seguintes, apresentaremos algumas falsificações da Turquia, segundo seu gênero arqueológico. As fontes principais de material são os museus arqueológicos regionais.

2 O jornal Bugün, de 23 de março de 2014, revelou um falsário turco, dizendo que este é amplamente apresentado no circuito de compras e vendas de material arqueológico, e que ele trabalhava principalmente com métodos tradicionais. Esta é uma comparação que pode ser feita uma com um falsário alemão: Neidhardt (2010).
A melhora na cultura das pessoas, juntamente com o aumento progressivo do seu padrão de vida, tornou o hábito de colecionar mais "democrático", ainda que nos últimos séculos isso se restringisse a alguns poucos exemplos entre as classes dominantes (Brodie, Doole \& Renfrew 2001: 6). Referimo-nos à coleta de antiguidades - que muitas vezes se beneficiou das más condições econômicas de antigas terras ricas - originadas nos tribunais que se expandiram para a nobreza desde o Renascimento (Brodie \& Renfrew 2005: 245). A abertura de grandes museus transformou esses últimos em sucessores na demonstração de poder, que era até então reservada às coleções reais. Logo, muitos deles não hesitariam em transferir para suas coleções arqueológicas artefatos vindos de outros países, frequentemente adquiridos através de escavação ou do comércio com os antiquários. É desnecessário mencionar os Mármores de Elgin $^{3}$ no Museu Britânico, porém muito mais significativo para a Turquia é o caso do Altar de Zeus, de Pérgamo, em Berlim ${ }^{4}$. Os esforços dos

3 Os Mármores de Elgin, também conhecidos como os "Mármores do Partenon", são uma coleção de esculturas gregas clássicas em mármore (principalmente da autoria de Fídias e seus assistentes), inscrições e elementos arquitetônicos que originalmente eram parte do Partenon e de outros edifícios na Acrópole de Atenas. Thomas Bruce, o $7^{\circ}$ conde de Elgin, obteve uma polêmica autorização das autoridades otomanas para remover partes do Partenon, enquanto servia como embaixador britânico junto ao Império Otomano de 1799 a 1803 . De 1801 a 1812, agentes a mando de Elgin removeram aproximadamente metade das esculturas remanescentes do Partenon, bem como elementos arquitetônicos e esculturas do Propileu e do Erecteion. Os Mármores foram transportados por mar para a Inglaterra. Lá, a aquisição da coleção foi apoiada por alguns, ao passo que outros compararam as ações de Elgin a atos de vandalismo ou pilhagem. Após um debate público no Parlamento e a subsequente aceitação, os Mármores foram comprados pelo governo britânico em 1816 e expostos ao público no Museu Britânico, onde estão até hoje numa galeria criada especialmente para eles, a Galeria Duveen. $\mathrm{O}$ debate persiste quanto ao destino do Mármores: eles deveriam permanecer no Museu Britânico, ou ser devolvidos a Atenas?

4 Em 1878, o engenheiro alemão Carl Humann deu início às escavações oficiais da Acrópole de Pérgamo, um esforço que durou até 1886. A escavação tinha por objetivo resgatar os frisos do altar e expor as fundações do edifício. Mais tarde, outras estruturas antigas foram reveladas. Após negociações com o governo turco otomano, foi estabelecido que todos os fragmentos de frisos encontrados passariam 
museus norte-americanos nessa empreitada são notáveis, pois desde o final do século XIX não pouparam nenhuma despesa para adquirir itens legal ou ilegalmente (Brodie, Doole \& Watson 2000: 23-24; Renfrew 2002: 16). O Museu Metropolitano de Arte (The Metropolitan Museum of Art) tem uma longa história nesse quesito, mas há outras coleções norteamericanas, como o Museu J. Paul Getty, em Malibu, e Dumbarton Oaks, em Washington/DC. Nas maiores casas de leilões na Suíça, Grã-Bretanha ou nos Estados Unidos, objetos provenientes de escavações clandestinas foram leiloados diversas vezes.

Conforme mencionamos, outras coleções ocidentais públicas contêm cópias e falsificações. No site e em publicações do Museu Britânico ${ }^{5}$, podemos ver várias delas, de esculturas a cerâmicas e intaglios. Nesta breve síntese, apresentaremos alguns casos relacionados a coleções encontradas em museus turcos.

\section{Tabuletas cuneiformes}

As primeiras falsificações desse tipo de artefato nos tempos modernos aparecem na coleção de Claudius James Rich (1786-1821), criada antes mesmo da decifração dessa escrita (Jones, Craddock \& Baker 1990: 169b). "Em torno de 1904, no período inicial do interesse por colecionar tabuletas cuneiformes, J. Edgar Banks, um explorador da Mesopotâmia e comerciante de tabuletas, estimava que quase $80 \%$ daquelas anunciadas para venda em Bagdá eram falsas" (Brumfield 2018). Em 2016, o diretor-geral de Antiguidades e Museus da Síria informou que aproximadamente $70 \%$ dos artefatos apreendidos no país são falsos.

Em 1987, Christopher B. F. Walker escreveu que "um número significativo de falsificações [era]

a ser propriedade dos museus de Berlim. Em Berlim, restauradores italianos reconstituíram os painéis que compunham o friso, a partir dos milhares de fragmentos que haviam sido recuperados. A fim de exibir o resultado e criar um contexto para tal, um novo museu foi construído em 1901 na Ilha dos Museus em Berlim.

Ver The British Museum (2007). feito na Turquia nos primeiros anos deste século [séc. XX], e é notável quantas tabuletas ainda circulam hoje no mercado" (Walker 1987: 59-60).

\section{Estátuas de pedra, estatuetas, sarcófagos e mosaicos}

As esculturas em pedra são as mais difíceis de falsificar, pois o instrumental usado no mundo antigo desapareceu. Contudo, as pedreiras de mármore, como Docimium e Synnada na Frígia, permanecem as mesmas (Barresi 2003; Pensabene 1998). Hoje em dia, a Frígia fornece o mesmo mármore que há dois mil anos.

As estatuetas de pequeno porte em mármore frígio destinadas ao culto doméstico são as mais imitadas, juntamente com os deuses do panteão romano. Para fazer uma análise estilística precisa, vemos que as estatuetas dos museus locais na Frígia são selecionadas como modelos (uma estátua original de Hércules nos Estados Unidos foi substituída por uma falsa do Museu de Afyonkarahisar) ${ }^{6}$. Outros exemplos são encontrados em Usak, Denizli e Kütahya?.

As marcas na superfície deveriam ser suficientes para indicar que pedreiros modernos usaram equipamentos atuais. Às vezes, a superfície é envelhecida com a aplicação de uma pátina artificial, e recorre-se até mesmo a enterrar a estatueta por algum tempo. Nesses casos tanto a superfície quanto o estilo parecem bastante artificiais. A maioria dessas falsificações é um tanto ambivalente e caricatural, assim como lhes falta harmonia. Nos últimos anos, o número de falsos sarcófagos e osthotekai tem subido. Há cópias de composições conhecidas de figuras individuais detalhadas de representações famosas.

Embora seja difícil falsificar um mosaico, houve várias tentativas na Turquia. Os mosaicos das regiões ao Sul, como Gazientep e Hatay, foram forjados com frequência. Na maior

6 No Museu de Afyonkarahisar, há dois selos bizantinos falsos. (Bulgurlu \& İlaslı 2003: 131).

7 Sobre as falsificações de Kütahya, ver Colomban, Laveaucoupet \& Milande (2005). 
parte dos casos, o uso incorreto das pedras ou a ausência da tinta verdadeira colocam sua autenticidade em dúvida (Fig. 19 e 20).

\section{Estátuas e estatuetas de bronze}

A maioria das estátuas de bronze da Ásia Menor é encontrada embaixo d'água, próximo a navios afundados. A descoberta de estátuas de bronze em contextos arqueológicos determinados é rara. A técnica de fundição "cera perdida" parece ser atraente para os falsários. As proporções das obras em bronze são frequentemente inapropriadas. A pátina do bronze não pode ser reproduzida, portanto, a superfície das falsificações parece mais polida, e até marcas de técnicas modernas de fundição podem ser percebidas. Em função das técnicas de fundição utilizadas, os objetos modernos são mais pesados que os antigos. Em figuras de menor tamanho, os mesmos erros ocorrem. Hoje, é difícil remover os rastros em estatuetas de pequeno porte. Essa é precisamente a razão pela qual é tão complexo distinguir entre verdadeiro e falso. A escultura ideal, não raro, é escolhida como modelo para um bronze de maior escala.

\section{Terracotas}

Na parte ocidental da Ásia Menor, havia, no período helenístico, vários centros de produção de terracotas, como Myrina e Smirna. No período romano, muitas dessas obras foram copiadas, em especial na Frígia. As terracotas frígias, que imitavam os modelos helenísticos, eram tão admiradas quanto aquelas de Myrina (Pottier \& Reinach 1888: 165-166; Uhlenbrock 1990: 27). Durante o século XIX, o dilúvio de falsificações de estatuetas de Tanagra se iniciou. Na atualidade, Afrodite (cat. n. 18-20) e outras figuras femininas são falsificadas regularmente. As contrafações modernas de terracotas são mais pesadas que as originais. As suas cores parecem artificiais. O orifício da queima é normalmente omitido, e a camada externa apresenta uma tonalidade diversa em relação às verdadeiras. As terracotas frígias mais simples são geralmente imitadas
(Fig. 19 e 20). Em objetos coroplásticos, a diferença estética entre uma falsificação e uma peça original é grande.

\section{Bronze, cerâmica, vidro e materiais variados}

Na Turquia, falsificam-se recipientes de bronze com muita frequência, sendo as lamparinas a categoria mais popular. Entretanto, cópias modernas são desmascaradas por causa das técnicas modernas de fundição.

Também a cerâmica é objeto usual de falsificações, mas essas podem ser detectadas graças às modernas técnicas de arqueometria. Os vasos forjados na Turquia raramente são convincentes, pois não conseguem imitar o barro antigo, e as peças normalmente são pouco cozidas. Nas ranhuras de um vaso de Cnido, por exemplo, um pó verde (sal de nitrato de cobre solúvel em água) foi encontrado (Fig. 21). Várias lamparinas e unguentários são também reconhecidamente falsificações. Para tais objetos, os falsários produzem uma camada de corrosão artificial por um processo de deposição química de vapor com ácido nítrico.

Falsifica-se vidro também, mas sua tecnologia de manufatura é problemática quanto ao reconhecimento das cores.

Imitações de brincos de ouro, prata e bronze são igualmente comuns. $\mathrm{O}$ maior problema consiste em reproduzir as antigas técnicas de produção. Algumas imitações combinam ourivesaria antiga com pedras modernas.

Joias em vidro e gemas são geralmente contrafações amadorísticas fáceis de detectar. Até artefatos menores, como fíbulas e flechas, são falsificados. Objetos cristãos bizantinos de liturgia são muito populares ultimamente, e seguidamente alterados.

\section{Moedas}

Na Turquia, os artefatos mais falsificados são as moedas gregas e romanas, especialmente de ouro e de prata. Tanto o padrão das letras quanto o estilo de apresentação são fatores-chave para determinar a autenticidade de moedas. Todavia, 
há muitas moedas falsas nas coleções turcas. Um fator crucial para identificar uma falsificação é o estudo da pátina, uma camada de deposição formada por influência do meio ambiente em achados arqueológicos através dos séculos (Sayles 2001: 2). Essa camada de corrosão é difícil de reproduzir. Outros fatores relevantes são o conteúdo de ouro e prata, e a reprodução correta das proporções padronizadas em uso durante a Antiguidade Clássica.

As moedas falsas turcas têm emendas nos bordos, têm bolhas, têm peso fora do padrão e um contorno irregular. A cópia é cunhada como na Antiguidade, com dois cunhos. Os cunhos são moldes do original, ou então gravados pelo forjador. Os sulcos gravados são minúsculos; ranhuras radiais no campo entre o retrato e o bordo ocorrem em moedas de ouro e prata. São particularmente fortes entre a legenda e o bordo, e podem ter uma forma ondulada. Os sulcos gravados têm origem no processo de cunhagem.

Falsificações apresentam uma emenda no bordo que precisa ser eliminada, e as marcas resultantes são quase sempre reconhecíveis. Às vezes, a emenda é irregular. Alguns bordos ficam com pequenas fissuras após o resfriamento, nestes casos, é usual colocar-se terra nas fissuras para dar a impressão de que a moeda tenha sido encontrada em escavações, em meio à terra.

Em moedas falsas, as linhas externas do bordo são muito afiadas, ou o rebordo, que ocorre durante o processo de cunhagem, está faltando. Contornos borrados, irregulares ou muito suaves são indicadores claros de falsificação. Falsificadores raramente imitam os cunhos criados pelos artistas romanos com todos os seus intrincados detalhes.

$\mathrm{O}$ aspecto mais importante das moedas contrafeitas na Turquia é seu estilo. Com frequência, a expressão facial, as dobras do tecido ou a posição dos olhos divergem do original. Drapeados e letras são especialmente difíceis de falsificar. Em alguns casos, um excesso de precisão pode ser um indício de falsificação, que poderia ser interpretado como algo "bom demais para ser verdade".

Diferentemente das moedas de bronze, as moedas de metais preciosos romanas tinham uma cunhagem restrita, com pesos padronizados.
Falsificações raramente têm o peso exato desejado. No processo de cunhagem, por exemplo, o peso não pode ser ajustado porque o volume é fixo. A cunhagem produz pequenas bolhas na superfície das moedas. O campo das moedas verdadeiras, exceto por raios gravados ou danos mecânicos, permanece sempre liso e plano, se não houver corrosão. Moedas gravadas encolhem ligeiramente quando resfriadas. Isso significa que todos os cunhos modernos são pequenos demais.

\section{Conclusão}

Raramente sabemos quando e por quem foram produzidas as falsificações na Turquia. Museus turcos tradicionalmente não discutem seus artefatos falsos de forma franca, para evitar o embaraço de admitir que foram enganados, e para manter a crença pública na sua competência. O roubo de 2006 marcou uma mudança revolucionária. A propósito do ocorrido, o jornalista Ömer Erbil que trabalhava no jornal Milliyet publicou importante furo, dizendo que uma peça-chave, um hipocampo dourado, havia sido roubado e trocado por uma falsa, e que moedas e uma pintura de parede de pássaro foram substituídas por réplicas também. O catálogo oficial publicado pelo Ministério da Cultura e Turismo turco após o retorno do tesouro lídio teve o hipocampo estampado na capa. O Ministério da Cultura e Turismo turco tem trabalhado para proteger os artefatos e garantir que sejam exibidos de maneira apropriada e segura. A Turquia já repatriou até agora 3.700 artefatos roubados por outros países nos últimos sete anos. Está em curso, felizmente, um esforço internacional para combater o saque de antiguidades (Atwood 2004; Bowman Proulx 2011, 2013; Brodie \& Renfrew 2005; Brodie \& Tubb 2002; Brodie, Doole \& Renfrew 2001; Renfrew 2002). Obviamente, o primeiro pré-requisito é convencer a população de que a pilhagem precisa ser abolida porque empobrece o patrimônio nacional ${ }^{8}$.

8 "Em alguns casos, saqueadores ameaçam fazendeiros que poderiam fazer denúncias às autoridades de um sítio antigo" (Bower 2009: 23). 
Para comparar falsificações, a Direção Geral do Patrimônio Cultural e dos Museus da Turquia compilou um banco de dados de objetos falsos? Por essa razão, um website oficial nos moldes do Art Loss Register (ALR) ${ }^{10}$ foi criado e adotado por outros países, como o Chipre. Um desafio para o futuro seria incluir em um catálogo todas as falsificações conhecidas na Turquia e examinálas em detalhe.

\section{Catálogo dos exemplos de falsificações e cópias arqueológicas na Turquia}

\section{Tabuleta cuneiforme}

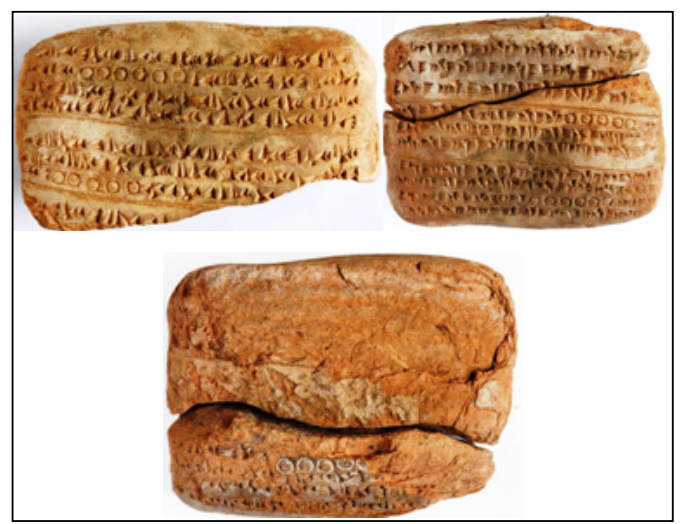

Fig. 2. Tabuleta "babilônica" cuneiforme.

Fonte: Museu Arqueológico de Istambul.

De acordo com Christopher B. F. Walker, uma "repetição excessiva de um pequeno grupo de sinais (neste caso, pequenos círculos) também é uma marca comum de um falsário sem imaginação" (Walker 1987: 60).

9 Nesse website, há cinco categorias de itens falsos em museus turcos: moedas, estátuas, miudezas, cerâmicas e diversos. Disponível em: https://bit.ly/2HQII7W. Acesso em: 07/04/2020.

10 Ver The Art Loss Register (2007) e, para a versão turca, T.C. Kültür ve Turizm Bakanlığı (2019).
Estátuas, estatuetas, sarcófagos e mosaicos

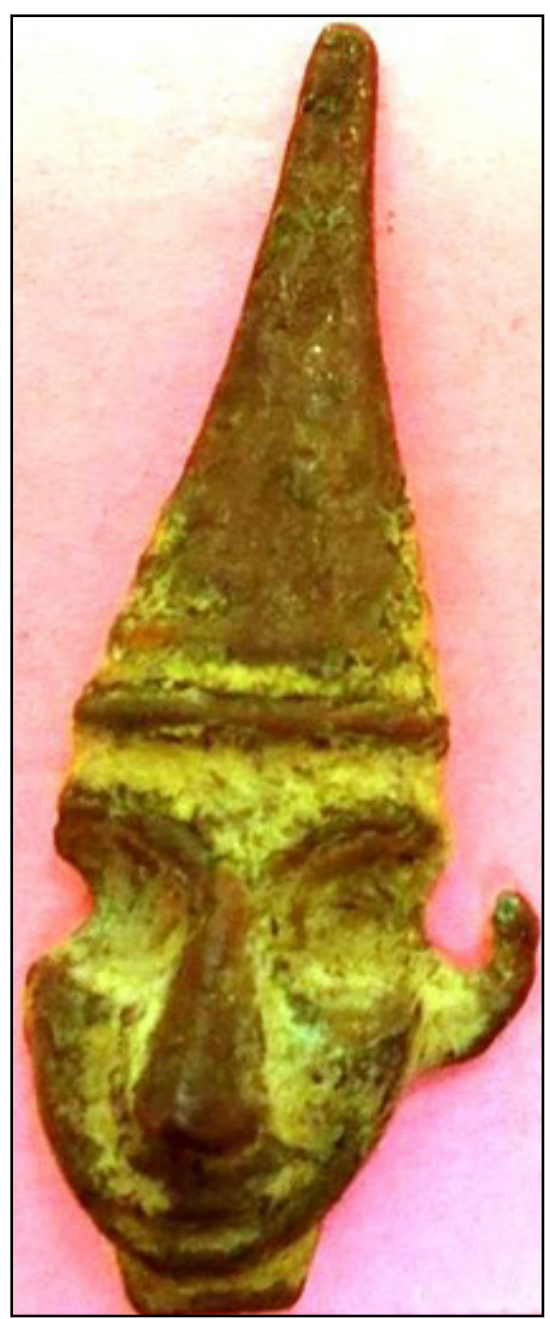

Fig. 3. Miniatura de busto "hitita" em bronze. Fonte: Museu de Osmaniye.

O chapéu cônico, os olhos grandes, o nariz maciço e longo, e a orelha saliente (quebrada) associam esta cabeça com as representações sírio-hititas de suas divindades, como Baal (Negbi 1976: 34-36, pl. XXIV XXV). São geralmente datadas dos séculos XII/XIII A.E.C. Neste caso, a estátua apresenta detalhes mal executados, como os olhos grandes e afundados, e foi feita de forma esquemática por alguém que desconhecia os exemplares originais. Talvez seja a cópia de um busto de bronze do deus hurritahitita Tešup, preservado no Museu de Amasya. 


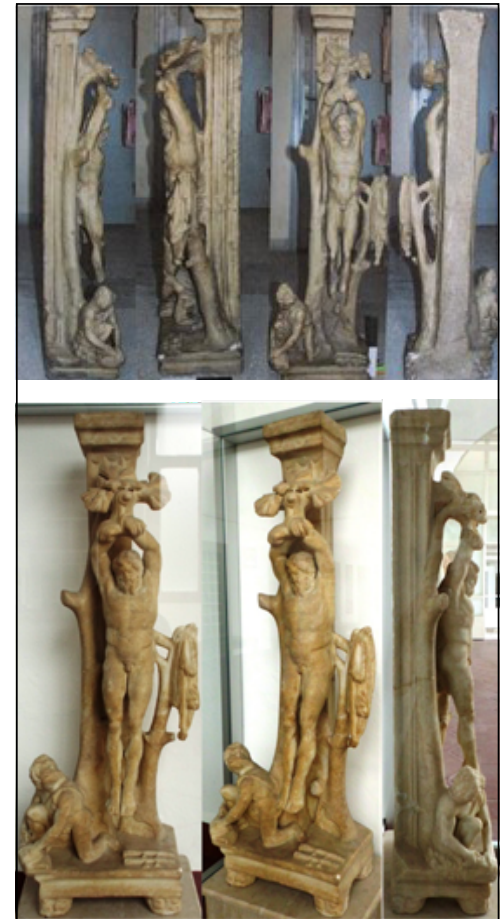

Fig. 4. Estátua de Marsias. Mármore cinzento. Fonte: Museu de Balikesir.

É uma cópia de uma estátua original do Museu de Manisa (Fig. 4) ${ }^{11}$, embora a cor da superfície seja negra em vez de branca ${ }^{12}$. Uma outra falsificação também de Marsias, do mesmo tipo, tamanho e estilo de execução, encontra-se no Museu de Eskisehir.

Um número considerável de réplicas do chamado "Marsias branco" esteve em circulação. Até a presente data, 59 foram divulgadas. $\mathrm{O}$ "Marsias vermelho", assim denominado devido ao mármore de veios avermelhados usado nos

11 O Marsias original do museu de Manisa foi obtido através de escavações ilegais no vilarejo de Bağlaca, próximo à Sarıöl, na província de Manisa, antiga Lídia, em 1987. Logo depois, foi transportado para fora da Turquia. As autoridades turcas acabaram por exigir sua devolução junto à Atlantis Antiquities em Nova York, em 1994. Para saber mais sobre seu retorno ao Museu de Manisa, ver T.C. Kültür ve Turizm Bakanlığı (1994).

12 Sobre as cópias da estátua de Marsias, ver Weis (1992, apêndice a). exemplos, foi inspirado nele ${ }^{13}$. A escolha do material provavelmente se deveu ao desejo de dar à sua pele flagelada a coloração apropriada.

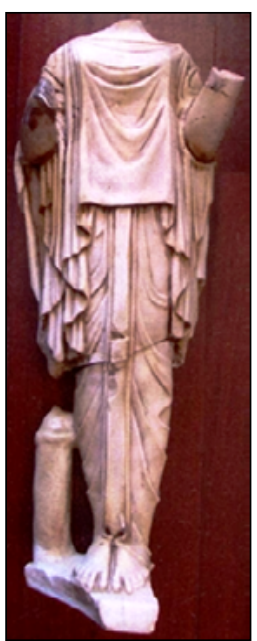

Fig. 5. Estátua "romana" de uma kore arcaica. Consiste em dois fragmentos; a cabeça desapareceu. Altura: $67 \mathrm{~cm}$. Mármore branco. Moldada.

Fonte: Museu de Burdur.

O braço esquerdo é muito grande e se articula artificialmente. A seção inferior da figura é estreita demais, e os pés apresentam dedos divergentes. $\mathrm{O}$ drapeado é completamente diferente dos padrões do período clássico.

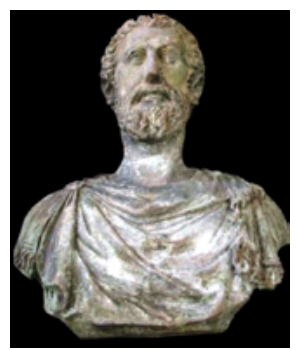

Fig. 6. Busto em bronze de Marco Aurélio. Dimensões: $50 \mathrm{~cm} \times 40 \mathrm{~cm}$

Fonte: Museu de Kayseri.

13 Sobre os "Marsias brancos" e "vermelhos", ver Sismondo Ridgway (2002: 86-87); sobre sua distribuição (vermelhos e brancos), pelo Oriente e Ocidente, ver Porter (2006: 152). 
O torso, quase em tamanho real, mostra o imperador em trajes cívicos. Assim, seria uma representação apropriada para o centro de uma cidade romana. A cabeça se assemelha à da estátua equestre dos Museus Capitolinos em Roma. Todavia, o bigode é mais espesso, e a barba, menos rebuscada. Tipicamente, esse elemento recebe sempre cuidado e atenção especiais mesmo em bronzes de menor porte, dada a importância da barba como característica "filosófica" do imperador, especialmente comum em contextos militares provinciais. $\mathrm{O}$ modelo pode ter sido copiado de um busto de mármore de Éfeso (Witschel 1995: 260).

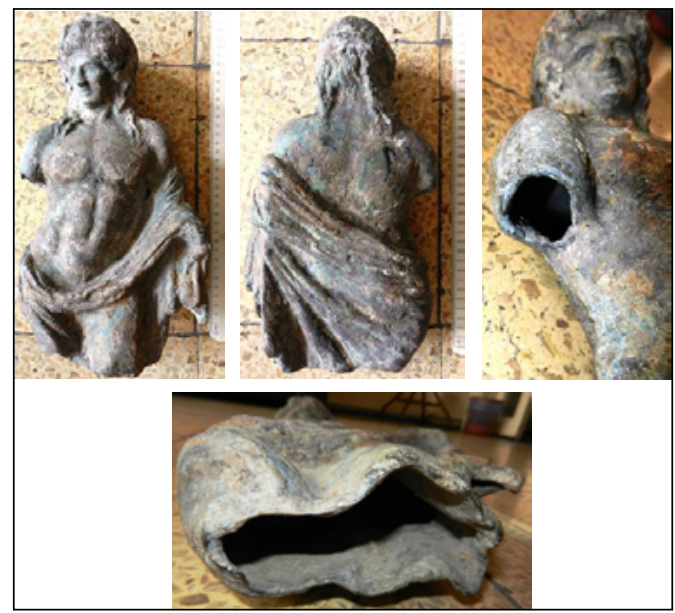

Fig. 7. Estatueta em bronze de Apolo. Altura: $35 \mathrm{~cm}$. Fragmentada.

Fonte: Museu de Konya.

Apolo de pé com a cabeça girada para a direita. A parte superior do corpo está desnuda, enquanto a inferior está envolvida nas dobras de um manto. É semelhante àquela que se encontra no Museu Hermitage. Os músculos peitorais são idênticos, assim como o design em geral. $\mathrm{O}$ artista reproduziu bem o cabelo e o drapeado sobre a perna esquerda. Os vestígios da fundição moderna, visíveis nas beiradas da parte quebrada - obviamente de propósito -, não deixam dúvidas.

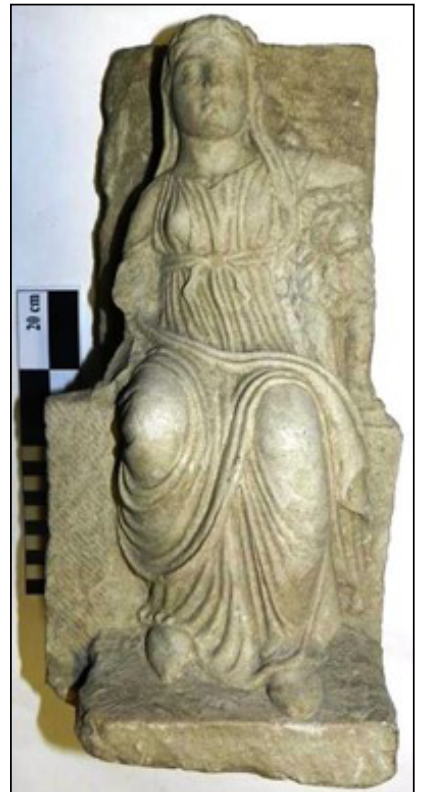

Fig. 8. Estátua em arenito de Cibele sentada. Dimensões: $37 \times 17 \times 17 \mathrm{~cm}$.

Fonte: Museu de Sakarya.

O modelo parece ser a estátua da deusa no trono do período helenístico, hoje no Museu das Civilizações da Anatólia de Ancara. Mas podemos ver um leão à sua esquerda, uma posição incomum: geralmente ele se encontra aos pés da deusa.

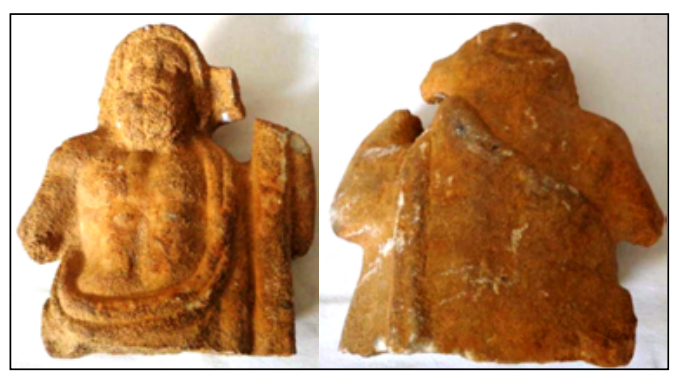

Fig. 9. Júpiter. Mármore. Fragmentada.

Fonte: Museu das Civilizações da Anatólia de Ancara.

A técnica do rosto, cabelo e finalmente sua anatomia são absolutamente infantis.

O drapeado é esquemático e bastante tosco. 


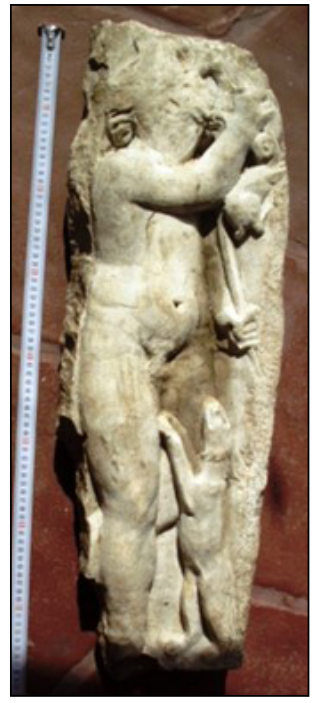

Fig. 10. Relevo de Eros com cão. Mármore. Fragmentado. Fonte: Museu de Manisa.

Vemos alguns problemas na flexão do braço e na transição do torso para a perna. A perna direita é toscamente executada, e o cão, amadorístico.

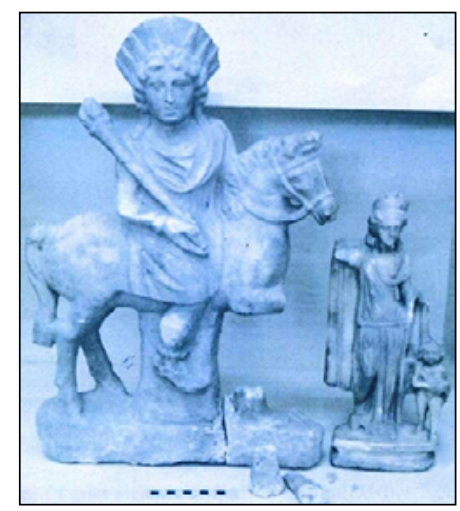

Fig. 11. Hélio a cavalo e estatueta de Afrodite. Dimensões: Hélio: H 58 cm; L 40 cm; Afrodite: H $37 \mathrm{~cm}$ L $18 \mathrm{~cm}$. Ambos em mármore.

Fonte: Museu de Antalya.

Além da representação usual do deus como cavaleiro, notamos aqui uma influência clara das imagens de Hélio, com a coroa de raios que surge no período helenístico inicial, como o condutor de carruagem na métopa do Templo de Atena em Ilium, hoje em Berlim. Na nossa estatueta, o ângulo frontal do peito é um tanto incomum, ao passo que a parte inferior do corpo está em perspectiva, como na arte arcaica. Também são inconsistentes as representações do braço direito, e em especial a do cavalo. Observa-se o expediente para produzir uma obra fragmentada e apresentar partes dispersas dela. Uma imagem em terracota de Hélio sentado, com os braços abertos, está preservada no mesmo museu em Antalya.

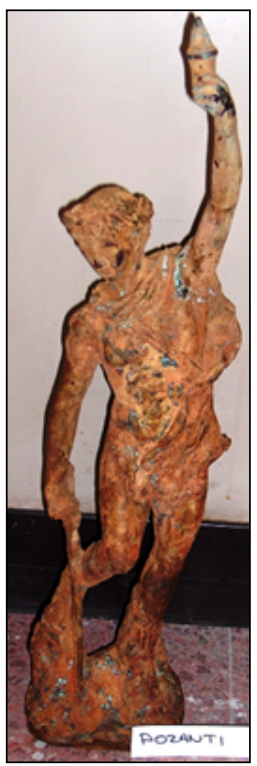

Fig. 12. Estatueta de um jovem. De Pozanti, ao norte de Adana. Altura: $51 \mathrm{~cm}$.

Fonte: Museu de Arqueologia de Adana.

Jovem usando túnica curta levantando um objeto com a mão esquerda (lanterna?), apoiado por um caniço na mão direita. Carrega uma bolsa (?) presa a um cinto pendendo de seu ombro direito.

A pátina é inteiramente moderna, a base é incongruente, e alguns detalhes, como a perna e o braço esquerdos, diferem da tradição clássica. 


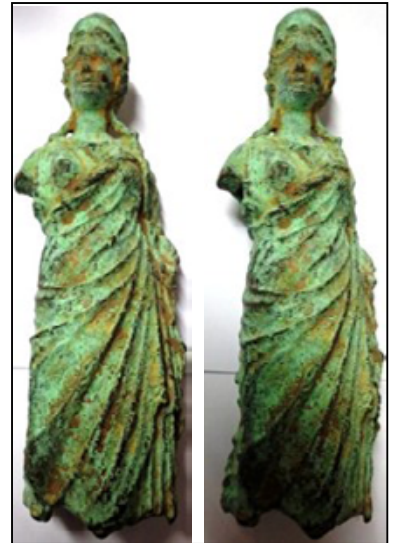

Fig. 13. Estatueta em bronze de uma jovem.

Fonte: Museu das Civilizações da Anatólia de Ancara.

Pelo diadema parece ser uma deusa ou imperatriz. As tranças remetem às imagens de Agripina, a Velha. A pátina, contudo, é bastante suspeita.

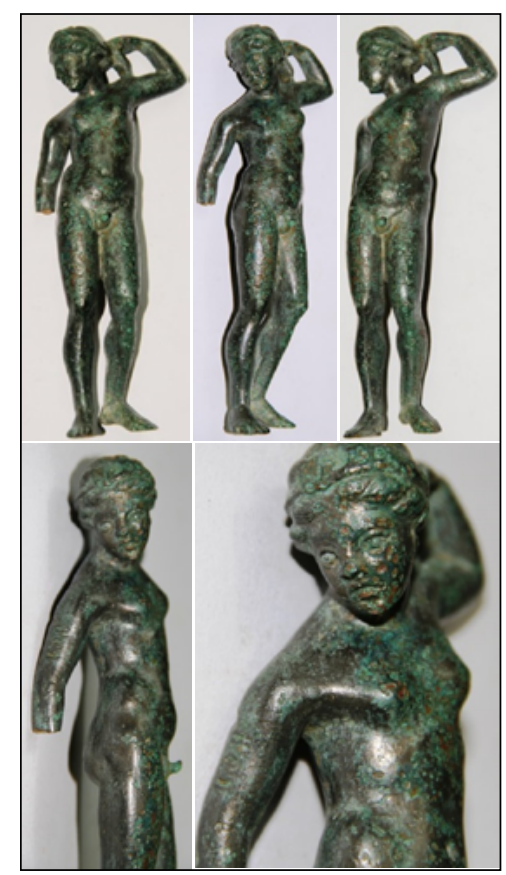

Fig. 14. Hermafrodita. № de inventário: $1745 . \mathrm{H} 16 \mathrm{~cm}$; L máx. 4,5 cm, L mín. 3,5 cm; peso: 363,8 g. Maciço. Falta a mão direita. Sem sinal da base. Pátina verde meio brilhante cobrindo a superfície. Falsa pátina marrom claro presente em vários lugares. Aquisição. Fonte: Museu de Ödemiş.
Estatueta em liga de bronze de nu masculino de pé, portando uma fita sob a qual se vislumbra uma faixa de cabelo ondulado. Sua cabeça está girada à esquerda, o braço esquerdo levado à cabeça, e a perna esquerda dobrada e ligeiramente recuada. Sua posição, no ato de se virar, mostra uma percepção erótica, conhecida na iconografia ligada à Afrodite. Sua mão direita ausente poderia estar segurando um espelho, como em muitos exemplares semelhantes. Ele tem seios pequenos, o que é comumente interpretado como "Hermafrodita". $O$ único indicador genital para seu gênero é seu pênis. As representações faciais para Afrodite são incomuns, pois os olhos são muito grandes e o nariz não se encaixa nas formas usuais ${ }^{14}$.

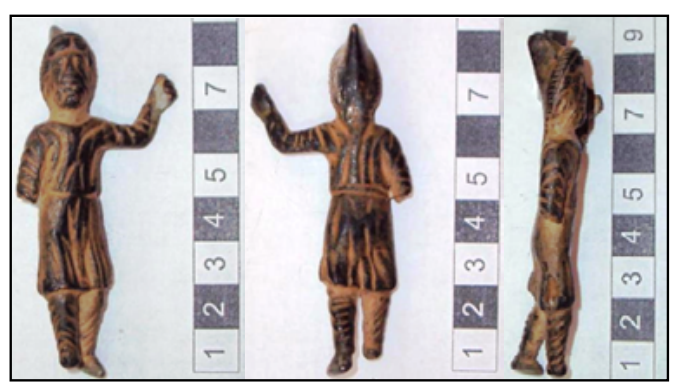

Fig. 15. Estatueta de Átis. H $8 \mathrm{~cm}$.

Fonte: Museu de Samsun.

A mão e o braço direitos estão faltando. Representa um tipo comum, aqui banalizado no barrete, nas dobras da roupa e nas pernas. Uma obra sem valor.

14 Ver Blanchet (1896: pr. 4); Babelon \& Blanchet (1895: 136, n. 307); Lasteyrie du Saillant (1890: 38, pr. VI-VII) e o exemplar no acervo do Museu Britânico sob o $\mathrm{N}^{\circ}$ de inv. 1848,0803.44. 


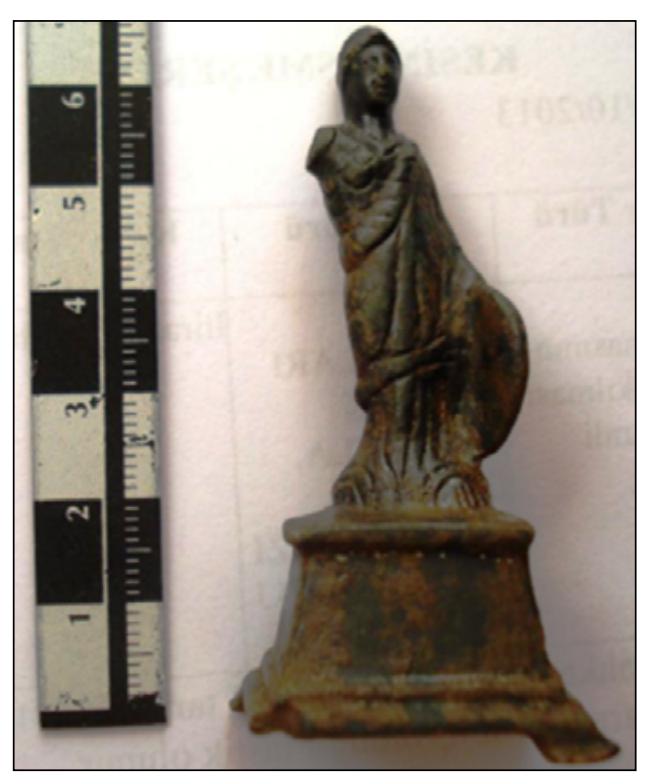

Fig. 16. Estatueta de Atena. Dimensões: $\mathrm{H} 7 \mathrm{~cm}$; base: $2 \mathrm{~cm}$.

Fonte: Museu de Konya.

Figura de pé, sem o braço direito que seguraria a lança, também faltando. Na mão esquerda segura o escudo. $\mathrm{O}$ gorgoneion no seu colo é estranho. A base, incomum, tem a forma de uma pirâmide truncada. A figura está em desequilíbrio, de tal forma que a lança, caso existisse, cairia para fora da base. Alguns detalhes são extremamente simplistas, como os pés, o pregueado e o caimento das vestes.

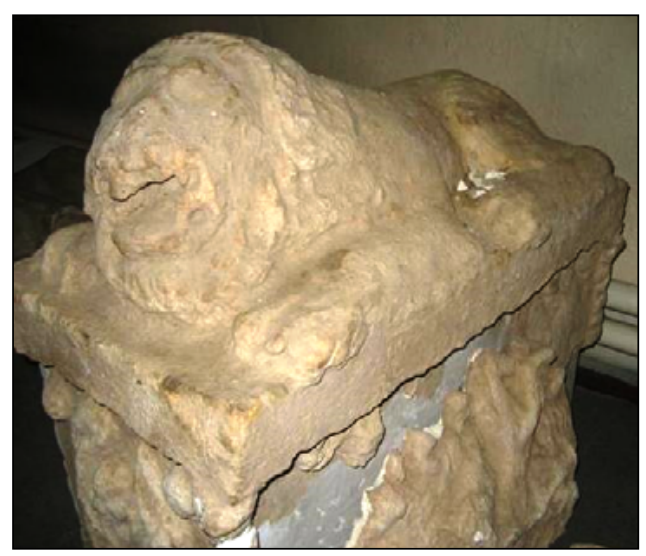

Fig. 17. Ossuário em calcário. Fragmentado. Fonte: Museu de Akşehir.
Há um leão na tampa, deitado no solo, com uma cabeça grande e formato circular. Pilares nos ângulos ladeiam cenas em relevo. Uma grande fissura na lateral foi preenchida com cimento.

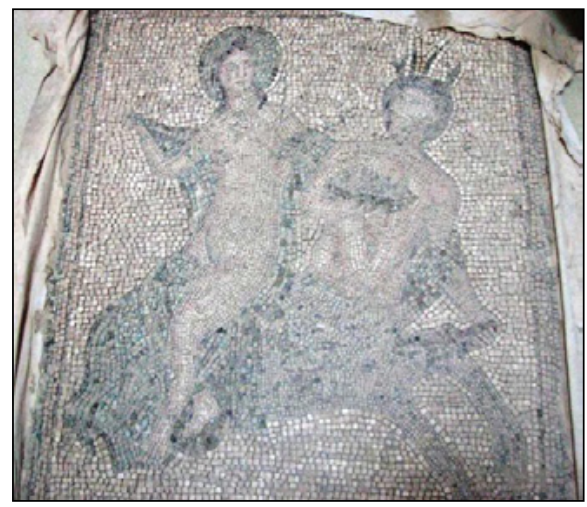

Fig. 18. Painel de mosaico. Dimensões: $105 \times 90 \mathrm{~cm}$. Fonte: Museu Arqueológico de Hatay.

O mosaico mescla os vários elementos da hierogamia de Dioniso e Ariadne - comparar com a cena retratada na cratera de Derveni que aparecem nos mosaicos de Antioquia. As cores são desbotadas, e a execução no geral não é fidedigna.

\section{Terracotas}

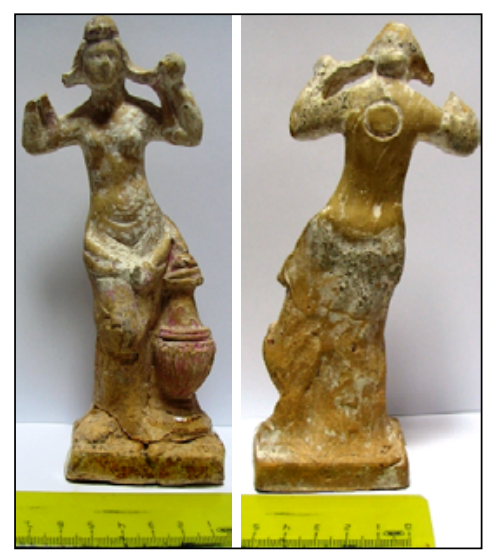

Fig. 19. Afrodite. Dimensões: H 18 cm; L 6,9 cm; base $1,5 \mathrm{~cm}$.

Fonte: Museu de Aydin. 
Vênus é retratada de pé, e ajeitando os cabelos, como a anterior. A única diferença é o vasilhame em vez do golfinho envolvendo a deusa. O golfinho se encontra tanto na estátua da chamada Vênus de Mazarin, na Villa Getty, quanto na estátua de mármore em tamanho natural da Vênus Anadyomene, também conhecida como a Vênus Marinha, presenteada pela Rainha Vitória a seu marido em seu aniversário no dia 26 de agosto de 1848; hoje na Coleção Real, Londres.

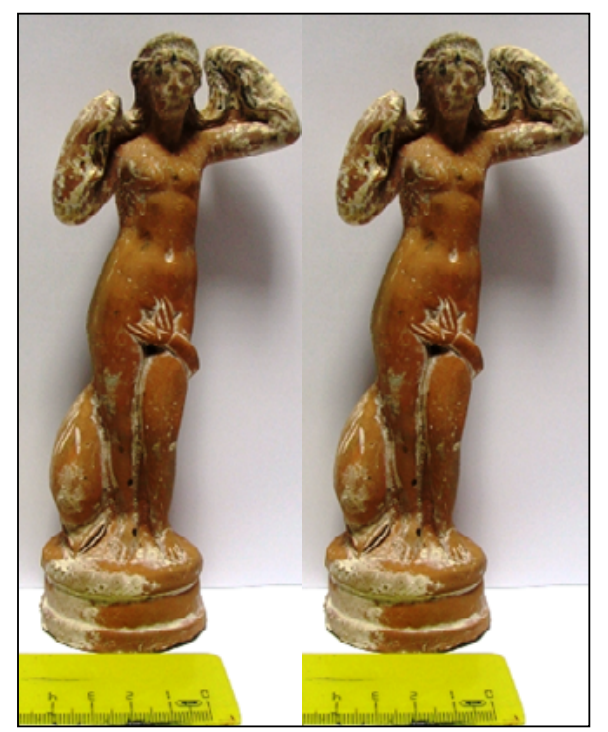

Fig. 20. Afrodite. Dimensões: H $17,2 \mathrm{~cm}$ L $6,5 \mathrm{~cm}$; base $2,5 \mathrm{~cm}$.

Fonte: Museu de Aydin.

A estatueta lembra o estilo helenístico em vigor ainda no período romano, em tamanho pequeno, também encontrado às vezes em pinturas e mosaicos, retratando o gesto típico de torcer os cabelos. Pode apresentar, como neste caso, um vaso em que se apoiam as vestes. Muitas estátuas de Vênus eram colocadas no banheiro. Esta estátua se assemelha a uma em mármore de Pompeia (Accademia Nazionale dei Lincei 1899: 206; Boyce 1937: 40, n. 118, nota 1). No nosso caso, a figura é oblíqua demais, como podemos ver nas costas. O fato de ser uma obra moderna é claramente indicado pelo orifício circular posterior, que imita o furo de ventilação das peças genuínas.

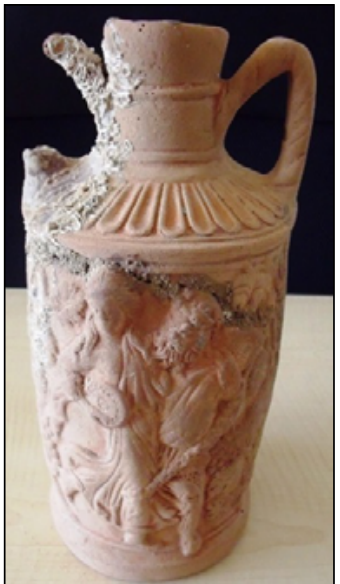

Fig. 21. Jarro "de Cnido" com relevos.

Fonte: Museu de Arqueologia de Adana.

Jarro de terracota ou "oinophoros", inspirado ou copiado do exemplar do Museu Britânico, de No 49-6-20.8 (Hayes 1972: 411-412, pr. XXIIa). O vasilhame original foi feito em Cnido, um porto de manufatura e comércio na Cária (sudoeste da Turquia). A decoração em relevo mostra membros do cortejo de Baco (uma mênade e um sileno). A pasta da superfície do relevo, com acabamento alisado, foi coberta com engobo marromavermelhado, característico dos ateliês de Cnido, em contraste com os produtos de Pérgamo. No nosso caso, além da presença dos elementos químicos citados, a borda e as alças são diferentes das originais (ex.: peça № 49.94.5, no Museu Metropolitan), ao passo que a base é similar.

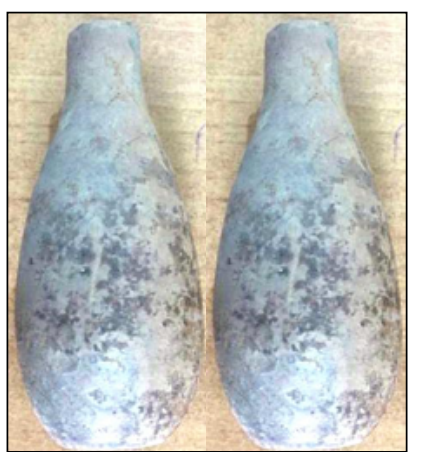

Fig. 22. Dois unguentários em terracota. Encontrados em Sarayköy, perto de Denizli. O engobo não corresponde de nenhum modo aos verdadeiros unguentos. Fonte: Museu de Denizli. 
Falsificações Arqueológicas na Turquia

R. Museu Arq. Etn., 36: 23-45, 2021.

Vidro

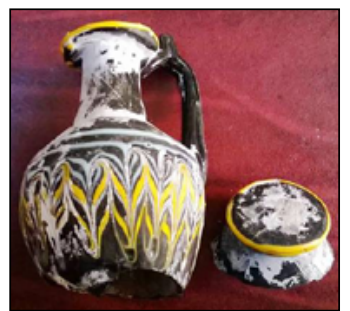

Fig. 23. Garrafa de vidro. Base quebrada.

Fonte: Museu de Hatay

A decoração do pescoço desapareceu e a imitação do vidro fenício é grosseira.

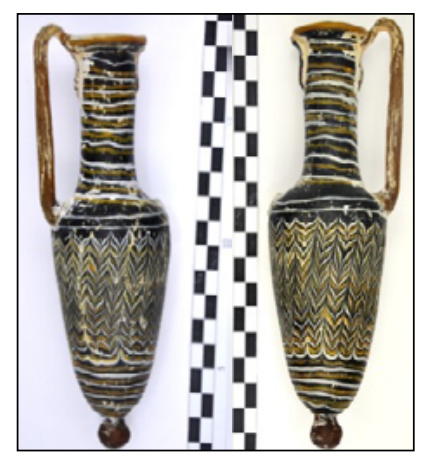

Fig. 24. Anforisco em vidro "fenício" com uma alça. Dimensões: H 15,5 cm; L 4,7 cm; borda $\varnothing 3,1 \mathrm{~cm}$.

Fonte: Museu de Sivas.

A alça e os filetes no pescoço são muito diferentes dos anforiscos originais.

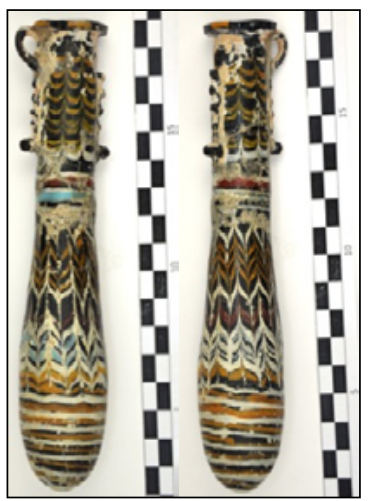

Fig. 25. Alabastro de vidro "fenício". Dimensões: H $15,5 \mathrm{~cm} ; \mathrm{L} \mathrm{4,7} \mathrm{cm}$; borda $\varnothing 3,1 \mathrm{~cm}$.

Fonte: Museu de Hatay.

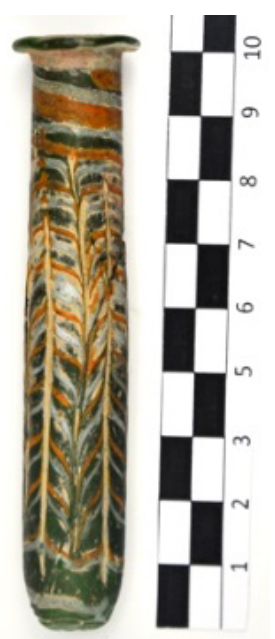

Fig. 26. Alabastro de vidro "fenício". Dimensões: H 9,1 cm; L 1,5 cm; borda: $\varnothing 1,9 \mathrm{~cm}$.

Fonte: Museu de Hatay.

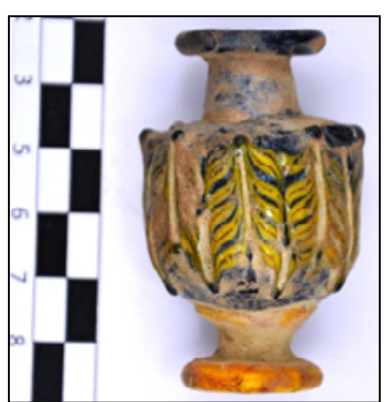

Fig. 27. Frasco de vidro "fenício". Dimensões: H 5,5 cm; L 3,4 cm; borda $\varnothing 2,3 \mathrm{~cm}$; base $\varnothing 2,1 \mathrm{~cm}$.

Fonte: Museu de Sivas.

Correspondência (perfil) com formas conhecidas é incerta.

O tipo de vidro parece suspeito.

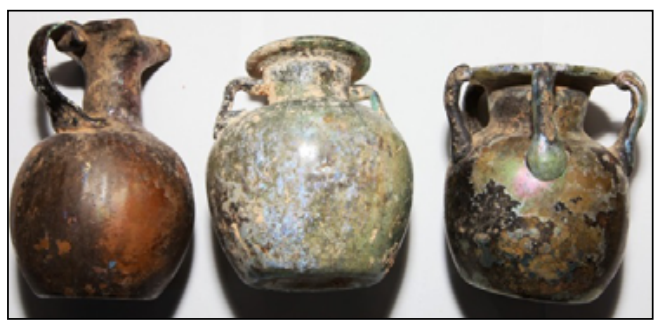

Fig. 28. Três frascos de vidro.

Fonte: Museu de Hatay. 


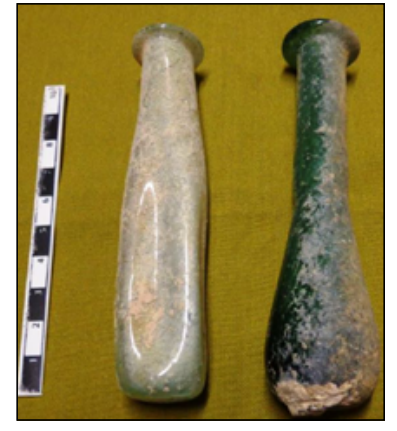

Fig. 29. Dois frascos de vidro.

Fonte: Museu das Civilizações da Anatólia de Ancara.

$O$ frasco da esquerda mistura formas diversas. $\mathrm{O}$ da direita combina um tipo de vidro egípcio com uma forma rara no Egito.

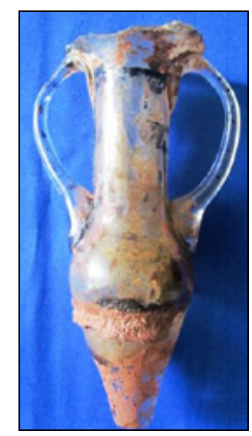

Fig. 30. Frasco fusiforme de vidro Fonte: Museu Etnográfico de Bitlis.

Sua forma é totalmente improvável, desconhecida na Antiguidade.

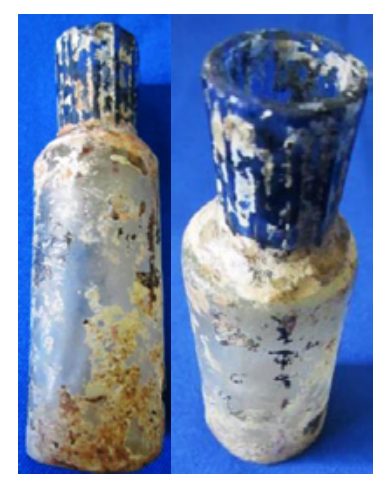

Fig. 31. Frasco de vidro.

Fonte: Museu Etnográfico de Bitlis.
A forma faz lembrar os vidros islâmicos do período medieval tardio, mas o tipo de vidro denuncia a imitação.

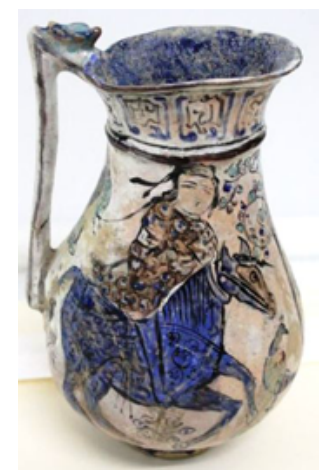

Fig. 32. Jarra de vidro decorada com uma alça. Dimensões: H 25,5 cm $\times 25,9 \mathrm{~cm}$; borda: $\varnothing 9,4 \mathrm{~cm} \times$ 10,2 cm: corpo: $\varnothing 14,5 \mathrm{~cm} \times 15 \mathrm{~cm}$.

Fonte: Museu de Arte Turca e Islâmica de Istambul.

A figura a cavalo estampada ficaria bem em uma peça vendida em lojas de souvenirs baratos.

A coloração do vidro revela sua fabricação moderna.

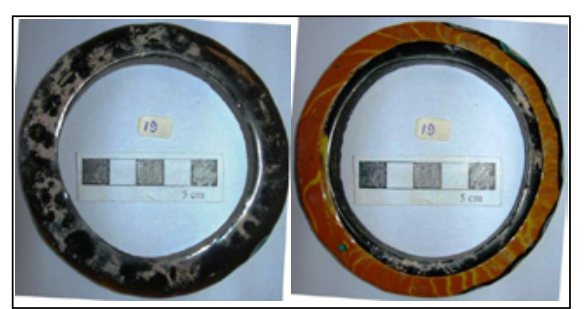

Fig. 33. Duas pulseiras de vidro.

Fonte: Museu de Arqueologia de Erzurum.

Joias

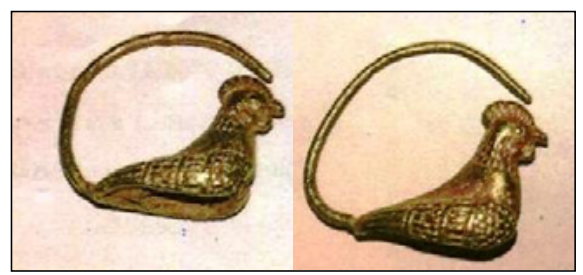

Fig. 34. Brincos de ouro.

Fonte: Museu Arqueológico de Izmir. 
A execução é grosseira em seus detalhes.

A parte superior do gancho e as pedras azuis incrustadas em ouro lembram um par de brincos do período helenístico no Museu de Arte Metropolitan ( $\mathrm{N}^{\circ}$ de inventário: 1995.539.11 a, b). A imagem no disco remete a representações dos períodos helenístico e romano (Von Bothmer et al. 1987: 307, n. 184).

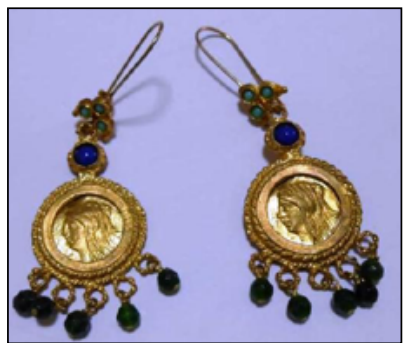

Fig. 35. Brincos de ouro e pedras preciosas. Fonte: Museu de Batman.

\section{Instrumenta}

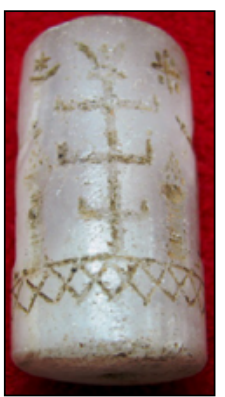

Fig. 36. Selo-cilindro. Adquirido de Bilal Keleş. Fonte: Museu de Bolu.

Parece um selo-cilindro sumério, mas a imagem não está correta.

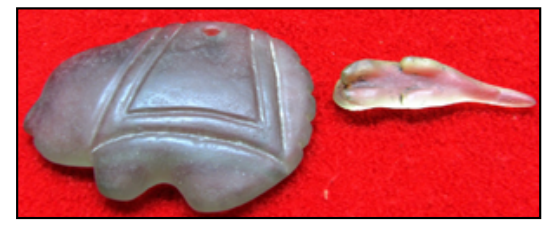

Fig. 37. Dois adornos gemológicos. Adquirido de Abdülkudüs Şen.

Fonte: Museu de Bolu.
Seu formato é inadequado.

As formas e tamanhos são tipicamente modernos, como as gemas dos séculos XVIII e XIX. Em alguns casos, a execução é totalmente diferente dos modelos antigos.

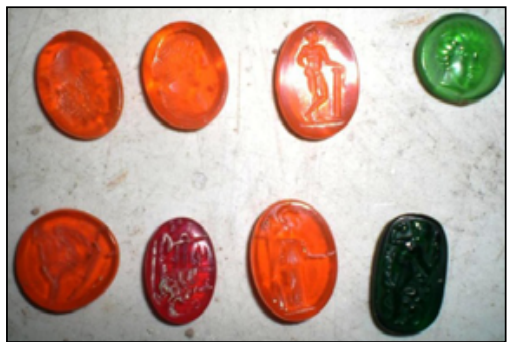

Fig. 38. Gemas.

Fonte: Museu Arqueológico de Izmir.

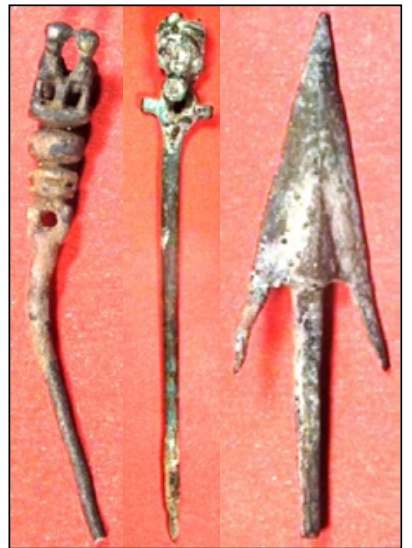

Fig. 39. Dois alfinetes de bronze e uma ponta de flecha. Fonte: Museu de Van.

Os alfinetes de bronze de Urartu têm outra aparência, e as flechas da Anatólia normalmente têm uma forma bastante diferente.

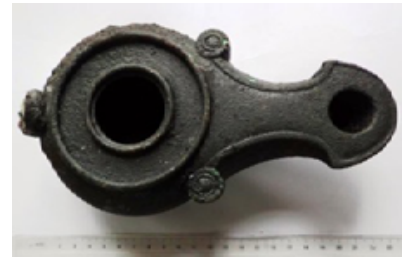

Fig. 40. Lamparina "romana” em bronze. L: $23 \mathrm{~cm}$. Fonte: Museu das Civilizações da Anatólia de Ancara. 
Semelhante às lamparinas com dupla voluta típicas de Mádia, porém brilhante demais, muito longa e sem pátina.

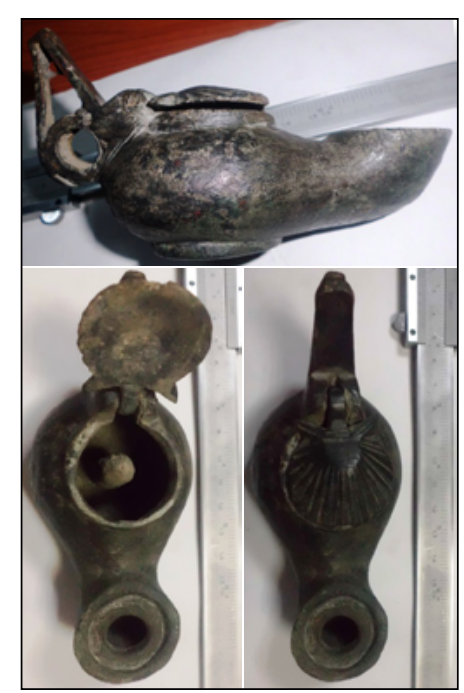

Fig. 41. Lamparina de bronze "tardoantiga". Dimensões: $\mathrm{H} 4,5 \mathrm{~cm}$; L $12 \mathrm{~cm}$; corpo $\varnothing 5 \mathrm{~cm}$; peso: $346,59 \mathrm{~g}$.

Fonte: Museu Arqueológico de Izmir.

O cabo não corresponde exatamente ao encontrado em lâmpadas a óleo antigas.

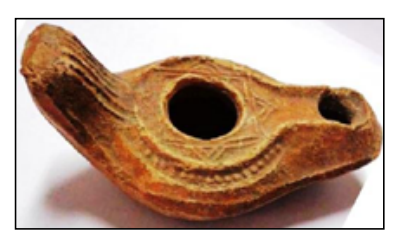

Fig. 42. Lamparina de terracota "tardoantiga".

Fonte: Museu das Civilizações da Anatólia de Ancara.

Lamparina com cabo em formato de língua, inspirada por modelos populares como Waagé (1948), tipo 53, Kennedy (1963), tipo 10, e Sodini et al. (1980), tipo 1, datados do século VI A.E.C. $O$ formato é similar. Um tanto diferente é a decoração em torno do infundibulum (cavidade em forma de funil). O tipo de material e o tratamento dado à superfície externa são dissemelhantes em relação aos originais.

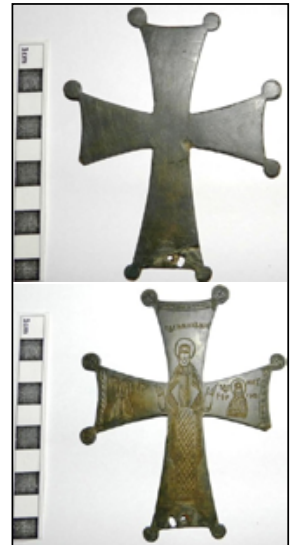

Fig. 43. Cruz de bronze "do período bizantino inicial". Fonte: Museu de Sakarya.

Esta deveria ser a imagem de São Jorge, mas a inscrição foi feita por alguém que desconhece o grego antigo, e a figura à direita é um busto de Madona, quando se esperaria a imagem de Cristo ao centro. $\mathrm{O}$ artista moderno não entendeu os modelos, como pode ser visto pelos pescoços e mãos. As vestes são excessivamente esquematizadas e geométricas. A incisão (feita por broca ou outra ferramenta) deixou um sulco plano e largo, e é extremamente incerta.

Moedas

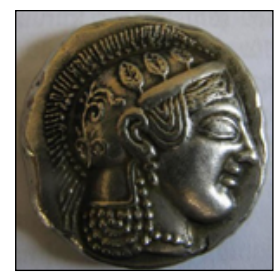

Fig. 44. Tetradracma de prata, Ática/Atenas, posterior a 449 A.E.C.

Fonte: Museu de Balikesir.

Anverso: Efigie de Atena laureada à direita, usando capacete e ornamentada de espirais de vinha. Larga demais: em vez de $24 \mathrm{~mm}$ de diâmetro, possui $35 \mathrm{~mm}$. As folhas de louro também diferem entre si. No lugar de um brinco redondo, apresenta um brinco em forma de cacho. 


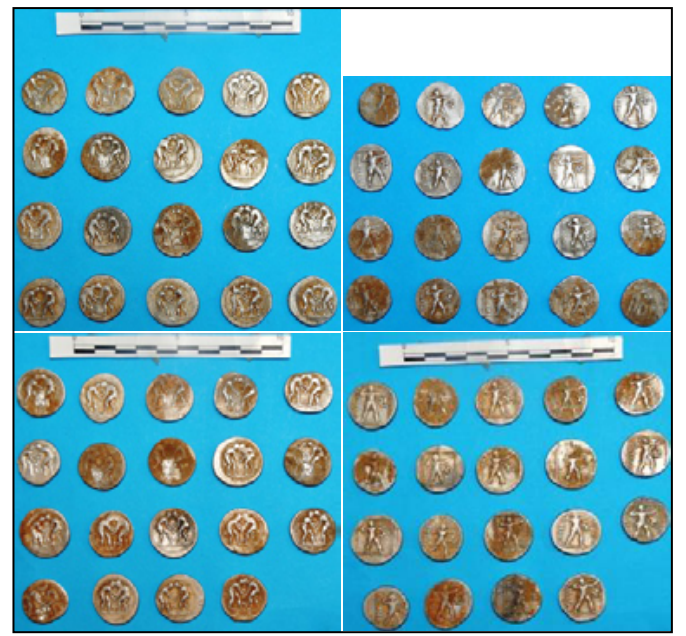

Fig. 45. 39 Estáteres de Aspendo, na Panfília, 370-325 A. E. C. Dimensões: $\varnothing 21 \mathrm{~mm}$; peso: $\mathrm{N}^{\circ} 1: 10,33 \mathrm{~g}$; No 6: 10,83 g; No21: 10,98 g; No26: 10,91 g.

Fonte: Museu Arqueológico de Izmir.

Anverso: Dois lutadores em ação. Em quase todos os exemplares sua expressão facial e musculatura são indecifráveis. Em muitos casos, a transição do torso para as pernas é muito estranha. A letra "A" é repetida diversas vezes.

Reverso: No campo esquerdo, há a inscrição greco-panfílica "E $\Sigma T \Phi \Delta E I I Y \Sigma$ ". O lançador em posição de atirar faz lembrar os feitos físicos gloriosos dos eventos olímpicos. No campo direito, há uma triskele de pernas humanas (emblema da cidade); abaixo dela, uma clava de Hércules e parte do " $\Phi$ ". Em várias moedas, a posição das triskeles - variável nas originais está incorreta. Às vezes, falta a linha vertical de pontos à direita, e a legenda contém erros.

Anverso: Alexandre, o Grande, como Hércules com a pele de leão. Os seguintes erros foram observados: representação esquemática do olho (=delta); falta de conhecimento sobre uma cabeça de leão, resultando em uma reprodução imperfeita; e representação sumária do cabelo.

Reverso: No campo, "A $\Lambda$ EEAN $\triangle \mathrm{POY}$, Zeus Aitophorus está sentado, segurando uma águia em sua mão estendida. Em alguns exemplares, o pescoço de Zeus e o nó sobre a cabeça do deus foram omitidos. Em algumas moedas as pernas do trono são ridículas.

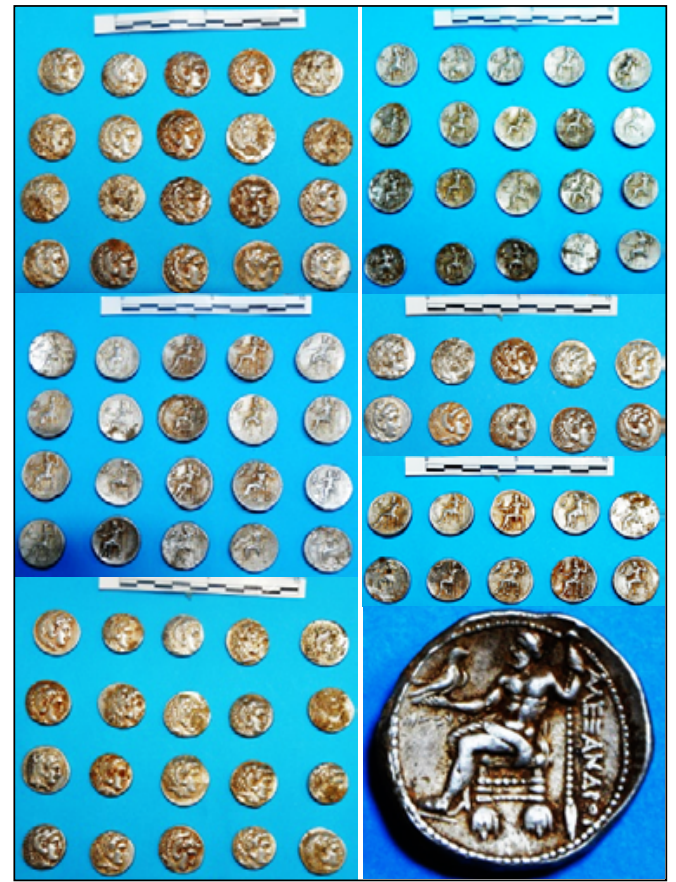

Fig. 46. 51 tetradracmas de prata de Alexandre, o Grande. Dimensões: $\varnothing 23 \mathrm{~mm}$; peso: № 1: 17,10 g; № 6: 17,14 g; No 21: 17,10 g; ํo 25: 17,20 g; No41: 17,13 g.

Fonte: Museu Arqueológico de Izmir.

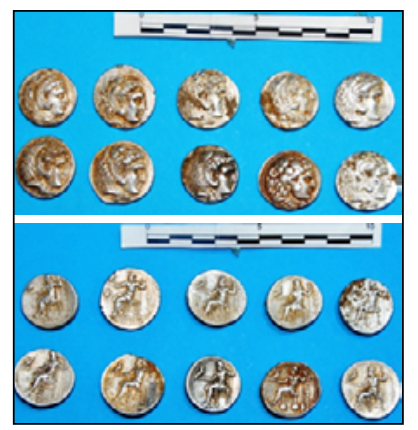

Fig. 47. 9 tetradracmas de prata de Filipe Arrideu. Dimensões: $\varnothing$ 22-23 mm; peso: $\mathrm{N}^{\circ} 1: 17,16 \mathrm{~g}$; $\mathrm{N}^{\circ} 6$ : $17,09 \mathrm{~g}$.

Fonte: Museu Arqueológico de Izmir.

Anverso: Alexandre, o Grande, com pele de leão.

Reverso: No campo, "BA $\mathrm{I} \Lambda \mathrm{I} \Omega \Sigma$ " e “ФІ ІІППОY", Zeus Aitophorus está sentado segurando uma águia em sua mão estendida. 
Em alguns exemplares a pele de leão está diferente, bem como os músculos de Zeus e o design do trono. A legenda está incorreta.

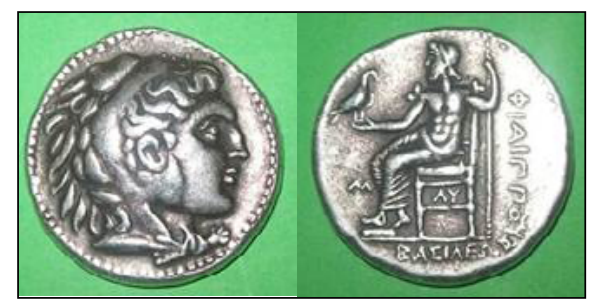

Fig. 48. Tetradracma de prata de Filipe Arrideu. Mesmo anverso e reverso do № 50 .

Fonte: Museu de Aksaray.

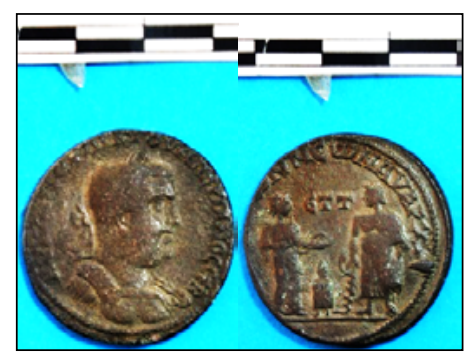

Fig. 49. Moeda de bronze de Egeia, na Cilícia, da época de Valeriano I (253-260 E. C.). Dimensões: $\varnothing$ $31 \mathrm{~mm}$; peso: $19,47 \mathrm{~g}$.

Fonte: Museu Arqueológico de Izmir.

Anverso: "AY KAY ПOY $\Lambda \mathrm{IK}$

OYA $\Lambda$ EPIANOC CEB”.

Reverso: Higea, Asclépio, Telésforo [АІГІЕ] $\Omega N$ NES NNAPXIC, e o ano E. T. T.

Detalhes falsos no lábio e na cavidade orbital do retrato.

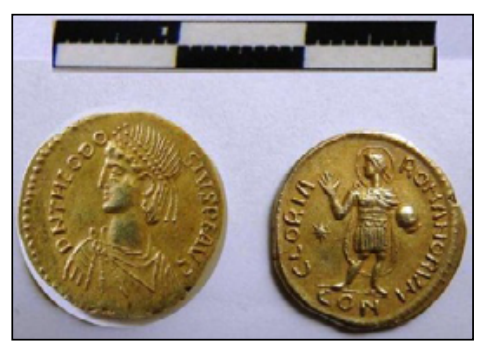

Fig. 50. Soldo de Teodósio II (402-450 E. C.). Fonte: Museu de Mersin.

\section{Anverso: "DN THEODOSIVS PF AVG".} Claramente uma falsificação devido às diferenças na execução do cabelo, dos olhos e das vestes.

Reverso: "GLORIA ROMANORUM"; exergo: "CON".

Estilo diferente do manto, que pende do braço direito ou do globo; tipos diferentes de letras ${ }^{15}$.

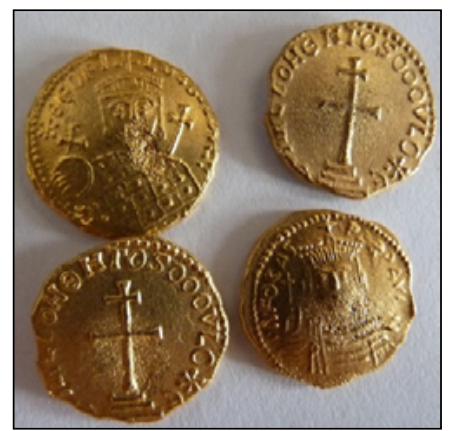

Fig. 51. Duas moedas de ouro da Imperatriz Irene (797-802 E. C.) e do Imperador Focas (602-610 E. C.).

Fonte: Museu de Balikesir.

\section{Anverso: "EIRINI BASILISSH". A} imperatriz não está corretamente apresentada, usando uma estola imperial bizantina (loros) e uma coroa com pontas e pendentes (pendilia); a legenda está errada e incompreensível.

Reverso: "dN FOCAS PERP AVC".

$\mathrm{O}$ retrato do imperador, usando o loros e a coroa com pontas e pendilia está errado.

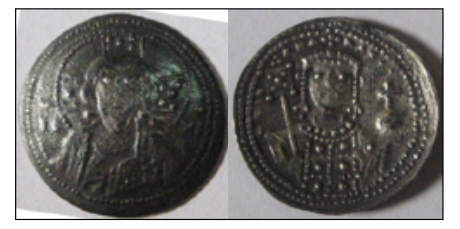

Fig. 52. Tetartero (tetarteron nomisma) de Aleixo Comneno (1081-1118 E. C.; cunhada entre 1081 e 1087).

Fonte: Museu de Akşehir.

15 Sobre falsificações de moedas bizantinas e sua verificação por métodos não-destrutivos de análises arqueométricas, ver Aydin \& Mutlu (2012). 
Anverso: Busto frontal do Cristo Pantocrator. Reverso: Busto frontal de Aleixo I Comneno coroado segurando cetro cruciforme e globo encimado por cruz (globus cruciger). Legenda ilegível.

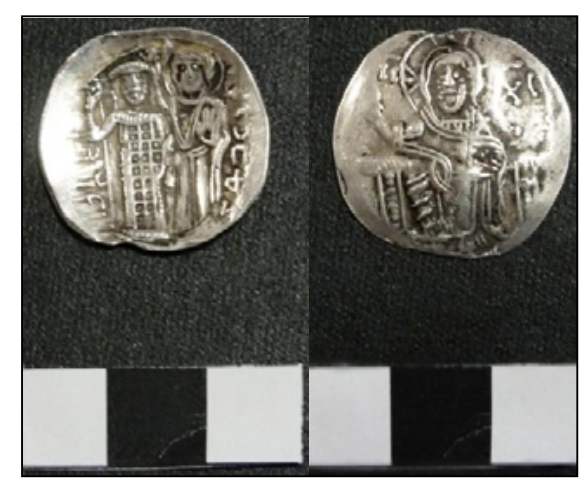

Fig. 53. Moeda de prata do Imperador Andrônico III Paleólogo (1328-1341 E. C.).

Fonte: Museu de Arqueologia de Usak.

Anverso: São Demétrio à direita e Andrônico III à esquerda.

Reverso: "IC XC" gravado no campo; Cristo no trono.

Desconhecimento acerca do drapeado; execução inexata das laterais do trono.

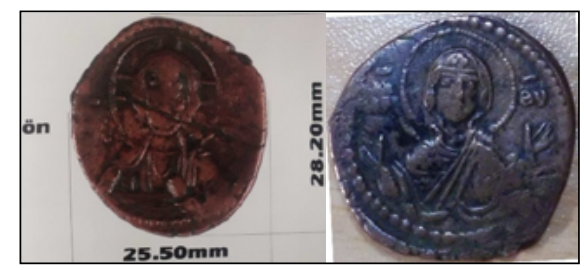

Fig. 54. Fólis anônimo de bronze de Romano IV Diógenes (1068-1071 E. C.).

Fonte: Museu Arqueológico de Izmir.

\section{Cunhagem de Constantinopla.}

Anverso: Busto de Cristo em posição frontal portando halo com cruz (nimbus cruciger), pálio e túnica (colobium), com a mão direita elevada em bênção, e um pergaminho na mão esquerda.

À esquerda, "IC", à direita, "XC". A orla apresenta colar de pérolas.
Reverso: Busto da Virgem rezando (Virgo Orans) em posição frontal, portando halo, pálio e maphorium (manto com véu). À esquerda, "MP", à direita, " $\Theta \mathrm{V}$ "; rodeado por colar de pérolas.

Há erros visíveis no pergaminho e no drapeado da imagem do Cristo; o lado direito do busto da Virgem Maria apresenta execução confusa.

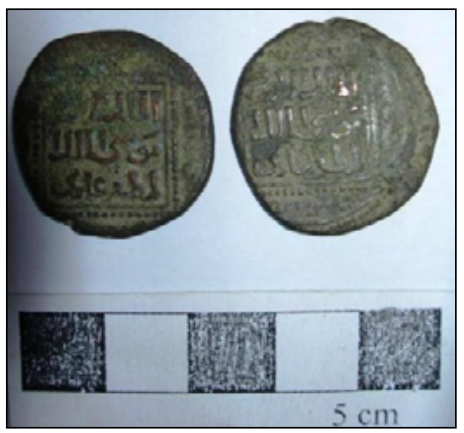

Fig. 55. Moeda islâmica de bronze do período medieval. Fonte: Museu de Arqueologia de Erzurum.

Semelhante às cunhagens de Saladino ou dos Aiúbidas. A legenda está ilegivel junto à borda.

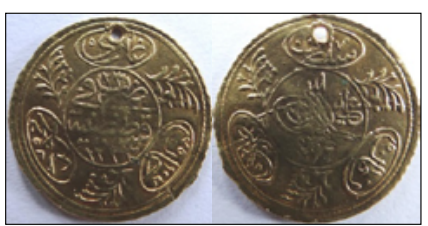

Fig. 56. Moeda otomana de ouro (Hayriye), Sultão Mamude II (1808-1839; a original foi cunhada em 1829). Adquirida em Hopa, Artvin.

Fonte: Museu de Rize.

O bordo original é mais baixo e não apresenta o serrilhado aqui presente.

\section{Notas e agradecimentos}

Esta coleção foi estudada em 2014 por E. Lafli graças a diversas autorizações concedidas pelo Ministério da Cultura e Turismo turco (Museu Arqueológico de Izmir, em 23 de fevereiro de 2012, autorização 
No B.16.0.K.V.M.4.35.00.01.155/604; e Museu de Ödemiş em 6 de janeiro de 2012, autorização No B.16.0.K.V.M.4.35.74.00-155.01/21). A maior parte das fotografias e o mapa 1 foram feitos pelo Dr. Sami Patacı (Ardahan) em 2014. Algumas das fotos foram retiradas do site do Ministério da Cultura e Turismo da Turquia (Fig. 4, 5, 8, 10, 11, 12, 13, 17, 21, 22, 31, 32, 33 e 46). Nossos agradecimentos à Jessica Silva Mendes pelo auxílio com a organização das imagens no texto.

LAFLI, E.; BUORA, M. GRADIM, C. Archaeological Fakes and Forgeries in Turkey. R. Museu Arq. Etn. 36: 23-45, 2021.

\begin{abstract}
In this paper we discuss archaeological authenticity in Turkey, advanced both from scholarly as well as popular scientific point of views. In the last five years in Turkey, the inconspicous debate on "archaeological authenticity" has become public. The problem was previously known, but not very common in scientific research. Turkish archaeologists probably a long way ahead to deal with this matter in scientific terms and accept it as an important study area. Although Turkey is a key country for both original and fake products, we know little about which materials should be categorized as replicas or fakes; which objects were falsified; what materials were falsified, why and by whom. The expected number of forgeries is very high in local museums exhibits, including lamps, coins, metal objects (especially silver) and gems. In international markets, we know several classes that have been forged in Turkey. It is particularly difficult to distinguish authentic coins or modern fakes. In the last ten years, Turkish museums were involved in several forgery scandals. These deceptions have two explanations: either the Museum managers know nothing about them, or there are other reasons for these pieces to be presented as real artifacts. This paper presents a sampling catalogue for the reanalysis of the artifacts using multiple criteria to determine their non-authenticy.
\end{abstract}

Keywords: Archaeological fakes; Replicas; Imitations; Authentic; Turkish museums.

\title{
Referências bibliográficas
}

Accademia nazionale dei Lincei. 1899. Notizie degli scavi di antichità. <https://bit.ly/3yJCDPN $>$. Acesso em: 7 jul. 2014.

Atwood, R. 2004. Stealing history: tomb raiders, smugglers, and the looting of the Ancient World. St. Martin's Press, New York.

Aydın, M. 2013a. Müze Kolleksiyonlarında Bulunan Antik Çă̆ Metal Eserlerinin Orjinalliğinin Korunmasında Tahribatsız Arkeometrik Yöntemler. In: Anais do $3^{\circ}$. ODTÜ Arkeometrik Çalıştayı. Türkiye Arkeolojisinde Metal:
Arkeolojik ve Arkeometrik Çalışmalar, 2013, Ankara, 166-172.

Aydın, M. 2013b. Authenticity of Roman Imperial Age silver coins using non-destructive archaeometric techniques. Dissertação. Middle East Technical University, Ankara.

Aydın, M.; Mutlu, S. 2012. Bizans Dönemi'ne Ait Altın Sikke Orijinalliğinin Tespitinde Tahribatsız Arkeometrik ve Görsel Analiz Yöntemlerinin Kullanılması. In: Akyol, A.A.; Özdemir, K. (Eds.). Türkiye'de Arkeometrinin 
Ulu Çınarları. Homer Kitabevi, Istanbul, 97-106.

Babelon, E.; Blanchet, A. 1895. Catalogue des bronzes antiques de la Bibliothèque nationale. Eugène Piot Foundation, Paris.

Barresi, P. 2003. Province dell'Asia Minore. Costo dei marmi, architettura pubblica e committenza. L'Erma Di Bretschneider, Rome.

Blanchet, J.-A. 1896. Statuette d'Hermaphrodite. Revue archéologique 3: 160-162.

Bower, B. 2009. Archaeologists tracing the labyrinth of antiquities trafficking hope to shut it down, or at least slow it up. Science News 175: 20-23.

Bowman Proulx, B. 2011. Trafficking in Antiquities. In: Smith, C.; Zhang, S.; Barberet, R. (Eds.). Handbook of International Criminology. Routledge, New York, 192-199.

Bowman Proulx, B. 2013. Archaeological Site Looting in "Glocal" Perspective: Nature, Scope, and Frequency. AJA 117: 111-125.

Boyce, G.K. 1937. Corpus of Lararia of Pompei. Memoirs of the American Academy in Rome 14: 5-112.

Brodie, N.; Doole, J.; Renfrew, C. (Eds.). 2001. Trade in illicit antiquities: the destruction of the world's archaeological heritage. McDonald Institute, Cambridge.

Brodie, N.; Doole, J.; Watson, P. 2000. Stealing history. the illicit trade in cultural material. McDonald Institute, Cambridge.

Brodie, N.; Renfrew, C. 2005. Looting and the world's archaeological heritage: the inadequate response. Annual Review of Anthropology 34: 343-361.

Brodie, N.; Tubb, K. (Eds.). 2002. Illicit antiquities: The theft of culture and the extinction of archaeology. Routledge, London.
Brumfield, S. 2018. How to spot fake cuneiform tablets. Friends of asor 6. Disponível em: <https:// bit.ly/2TzwROe>. Acesso em: 4 jul. 2020.

Bulgurlu, V.; İlasl1, A. 2003. Seals from the Museum of Afyon (Turkey). In: Cheynet, J.-C.; Sode, C. (Eds.). Studies in Byzantine Sigillography. Walter de Gruyter, Berlin, 131-149.

Colomban, P.; Laveaucoupet, R.; Milande, V. 2005. Onsite Raman Analysis of Kütahya Fritware. Journal of Raman Spectroscopy 36: 857-863.

Craddock, P. (Ed.). 2009. Scientific investigation of copies, fakes and forgeries. Oxford, Oxford University Press; Butterworth-Heinemann.

Hayes, J.W. 1972. Late Roman Pottery. London, British School at Rome.

Holtorf, C. 2013. On pastness: a reconsideration of materiality in archaeological object authenticity. Anthropological Quarterly 86: 427-443.

Jones, M.; Craddock, P.T.; Barker, N. 1990. Fake? The art of deception. University of California Press, Los Angeles. Exhibition catalogue.

Kennedy, A. 1963. The development of the lamp in Palestine. Berytus 14: 67-115.

Lasteyrie du Saillant, R.-C. 1890. Album archéologique des musées de Province. E. Leroux, Paris.

Mezzasalma, A.M. et al. 2009. Ancient coins and their modern fakes: an attempt of physico-chemical unmasking. Mediterranean Archaeology and Archaeometry 9: 15-28.

Negbi, O. 1976. Canaanite gods in metal: an archaeological study of ancient Syro-Palestinian figurines. Tel Aviv University, Tel Aviv.

Neidhardt, M. 2010. Replik: Handarbeit in alter Tradition. Disponível em: <https://bit. ly/3jJZymd>. Acesso em: 7 jul. 2014.

Pensabene, P. (Ed.). 1998. Marmi antichi II: cave e tecnica di lavorazione, provenienze e 
distribuzione. In: Proceedings of Seminario di archeologia e storia dell'arte graeca e romana dell'Università di Roma La Sapienza, 1998, Rome.

Porter, J.I. (Ed.). 2006. Classical pasts: the classical traditions of Greece and Rome. Princeton University Press, Princeton.

Pottier, E.; Reinach, S. 1888. La Necropole de Myrina. E. Thorin, Paris.

Renfrew, C. 2002. Loot, legitimacy, \& ownership. Bristol Classical Press, London.

Sayles, W.G. 2001. Classical deception: counterfeits, forgeries and reproductions of ancient coins. Krause, Iola.

Sismondo Ridgway, B. 2002. Hellenistic sculpture 3: the styles of $\mathrm{ca}$. 100-31 B.C.

University of Wisconsin, Madison.

Sodini, J.-P. et al. 1980. Déhès (Syrie du Nord). Campagnes I-III (1976-1978). Syria 57: 234-266.

Spier, J. 1990. Blinded with science: the abuse of science in the detection of false antiquities. The Burlington Magazine 132: 623-631.

T.C. Kültür ve Turizm Bakanlığı. 1994. Marsyas Heykeli (A.B.D.). Disponível em: <https://bit. ly/2HORJ1R>. Acesso em: 11 mar. 2021.

T.C. Kültür ve Turizm Bakanlığı. 2019. Koleksiyonculardan Çalınan/Kaybolan
Kültür Varlıkları. Disponível em: < https://bit. ly/3rHBbL4>. Acesso em: 7 abr. 2020.

The Art Loss Register. 2007. Disponível em: <https:// bit.ly/3eqXPU4>. Acesso em: 7 abr. 2020.

The British Museum. 2007. Explore the collection. Disponível em: <https://bit.ly/3l4KlPf $>$. Acesso em: 7 jul. 2014.

Uhlenbrock, J. 1990. The Coroplastic's Art. Greek Terracottas in Hellenistic World. Aristide d Caratzas Pub, New Rochelle.

Von Bothmer, D. et al. 1987. Antiquities from the Collection of Christos G. Bastis, Emma Swan Hall. Philipp von Zabern, Mainz on Rhine.

Waagé, F.O. 1948. The Pottery. In: Elderkin, G.W. (Ed.). Antioch on the Orontes I: The Excavations of 1932 -1934. Princeton University, Princeton.

Walker, C.B.F. 1987. Reading the Past. Cuneiform. University of California Press, Berkeley.

Weis, A. 1992. The Hanging Marsyas and its copies: Roman innovations in a Hellenistic sculptural tradition. G. Bretschneider, Rome.

Witschel, C. 1995. Büste des Kaisers Marc Aurel. In: Stemmer, K. (Ed.). Standorte, Kontexte und Funktion antiker Skulptur. Ausstellungskatalog Berlin. Freunde \& Förderer der Abguss-Sammlung Antiker Plastik, Berlin, 257-262. 